\title{
Adaptasi Konserto pada Ensambel Gitar sebagai Upaya Pengayaan Bahan Ajar Matakuliah Ensambel
}

\author{
Andre Indrawan ${ }^{1}$ dan Kustap \\ Jurusan Musik, Fakultas Seni Pertunjukan, Insitut Seni Indonesia Yogyakarta
}

\begin{abstract}
ABSTRAK
Penelitian ini membahas sebuah upaya pengembangan formasi ensambel gitar dalam rangka pencapaian suatu kesetaraan artistik terhadap penyajian sebuah konseto untuk orkestra dan solois instrumen tiup. Proses penelitian ini diterapkan dalam konteks pembelajaran dan pengajaran paket mata kuliah Koor/ Orkes/ Ensambel (KOE) pada kurikulum pendidikan tinggi musik di Indonesia. Permasalahan utama yang dibahas dalam studi ini ialah bagaimana menerapkan repertoar orkestra pada sebuah ensambel gitar? Tujuan dari pemecahan masalah tersebut ialah untuk memperkaya materi pengajaran ensambel gitar yang termasuk salah satu kelompok studi dari paket kelas-kelas KOE. Kontribusi hasil penelitian ini adalah rekonstruksi model pembelajaran ensambel gitar dari tingkat menengah hingga tinggi. Guna mencapai target yang telah ditetapkan, penelitian ini dilakukan dengan menggunakan kombinasi metodologis di antara metode transkripsi musikologis dengan metode tindakan kelas yang diadopsi pada studi material dan proses belajar ensambel gitar. Permasalahan yang teridentifikasi disimpulkan dengan pembuatan prototipe aransemen baru sebagai alternatif materi pengajaran melalui proses pengolahan editorial. Penelitian ini menyimpulkan bahwa keterbatasan gitar dalam menghasilkan kesetaraan terhadap kulalitas artistik orkestra dapat diatasi tidak hanya dengan mentranskrip reduksi pianonya tapi langsung dari skor orkestranya. Oleh karena itu, ensambel gitar dapat menjadi alternatif yang lebih baik dari versi pengiring piano dalam menyajikan sebuah konserto dengan solis instrumen tiup, dan pada saat yang sama memperkaya repertoar ensambel gitar.
\end{abstract}

Kata kunci: Ensambel gitar, transkripsi, konserto

\begin{abstract}
The Adaptation of Concerto on a Guitar Ensemble as the Enrichment Effort of the Ensamble Teaching Materials. This study discusses an effort in developing guitar ensemble formation in order to achieve an artistic equality to the performance of a concerto for orchestra and wind soloist. This is applied in the context of Indonesian higher music education's curriculum for the class room teaching and learning of the choirl orchestral ensemble (COE) subject package. The main problem discussed in this study is how to apply an orchestral repertoireire to an ensemble guitar? The purpose of this study is to enrich the teaching material of guitar ensemble, which is one among the COE classes. The result of this study is contributed to the reconstruction of guitar ensemble teaching model from middle to higher grades. To achieve the target that have formerly been set, this study has combined musicological transcription method and the class room action research which are adopted to research material study as well as guitar ensemble learning process. Problems that had identified was concluded by prototyping the new arrangement through transcription process from the concerto repertoire as the teaching material alternative, by editorial treatment. This study concludes that the guitar limitedness to result the equality with the orchestral artistic quality could be overcome not by transcribing from its piano reduction but directly from orchestral score. Because of that reason, guitar ensemble could be a better alternative to the piano accompaniment in performing a concerto for a wind solist, and at the same time it enriches guitar ensemble repertoire.
\end{abstract}

Keywords: guitar ensemble, transcription, concerto

1 Alamat korespondensi: : Jurusan Seni Musik, ISI Yogyakarta, Jln. Parangtritis Km. 6,5 Sewon, Yogyakarta. E-mail: indrawan_andre@yahoo.com; Hp: 081804251709 


\section{Pendahuluan}

Proses pembelajaran musik di perguruan tinggi seni Indonesia didominasi oleh matakuliah-matakuliah vokasional. Kuliah-kuliah tersebut berpangkal dari studi ketrampilan individual instrumental/vokal sebagai inti dari kurikulum ilmuilmu musik. Studi ketrampilan individual instrumental dapat dikelompokkan menjadi dua, yaitu jenis-jenis instrumen solo dan jenis-jenis instrumen orkestra. Kelompok pertama adalah instrumeninstrumen solo yang memiliki kapasitas harmonis dan kontrapungtis, serta repertoarnya tidak memerlukan dukungan instrumen lain sehingga dapat tampil seorang diri di panggung. Jenis instrument ini adalah piano, gitar, dan harpa. Kelompok kedua ialah instrumen-instrumen melodis yang memerlukan instrumen lain sebagai pegiring dan secara umum masuk ke dalam instrumen orkestra, seperti: flute, trumpet, biola, klarinet, cello, dan kontrabass. Repertoar instrumen-instrumen melodis tersebut melibatkan piano sebagai instrumenpengiring. Tingkat ketrampilan tertinggi dari jenis-jenis instrumen ini ialah memainkan reperoar konserto yang merupakan salah satu formasi komposisi orkestra. Pada konserto seorang instrumentalis bermain solo dengan diiringi oleh orkestra.

Di antara kuliah-kuliah ketrampilan lain yang paling dekat dengan studi individual instrumental, ialah studi ketrampilan kolektif atau klasikal yang disebut: (1) koor untuk kolaborasi vokal pria dan wanita, (2) orkestra untuk kolaborasi berbagai kelompok instrumen, dan (3) ensambel untuk kelompok instrumen sejenis, atau kelompok vokal sejenis. Salah satu formasi ensambel kelompok sejenis ialah ensambel gitar klasik, hal ini mengacu pada jenis gitar yang digunakan, yaitu gitar klasik (untuk selanjutnya disebut "gitar" dan "ensambel gitar"). Karena sifat dasar gitar sebagai instrumen solo, maka repertoar asli untuk ensambel gitar sangat terbatas. Sehubungan dengan keterbatasan itu, bahan perkuliahan ensambel gitar mengandalkan aransemen baru yang dirancang sendiri oleh para dosen yang mengampu matakuliah tersebut.

Dari banyak tipe-tipe konserto Klasik bagian pertama Concerto in $G$ major for Flute, K.131, karya Wolfgang Amadeus Mozart (1756-1791) adalah bagian yang tidak terlalu rumit sehingga memungkinkan untuk diadaptasi pada ensambel gitar. Rancangan aransemen ini memberikan dua manfaat sekaligus, yaitu sebagai alternatif pengiring flute sekaligus sebagai pengayaan bahan ensambel gitar. Komposisi ini merupakan tipe-tipe konserto Klasik awal yang masih terpengaruh gaya Barok, khususnya gaya ritornello dan basso continuo, sehingga identifikasi penerapan bentuk sonata pada karya ini tidaklah mudah.

Permasalahan pada perkuliahan individual instrumental tingkat tinggi untuk instrumeninstrumen melodis ialah penyediaan orkestra pengiring yang solusinya telah lama dilakukan melalui perancangan ulang pada versi reduksi piano. Permasalahan pada ensambel gitar ialah formasi aransemen yang monoton dan keterbatasan perbendaharaan produk aransemen. Sebagaimana halnya studi individual instrumental, kuliah ensambel gitar juga tersusun dari enam tingkat, namun hingga kini belum ada produk silabus dan modul yang menampilkan perbedaan bobot tingkat-tingkat perkuliahan ensambel gitar.

Artikel ini membahas penerapan jenis repertoar konserto pada perkuliahan ensambel gitar sebagai upaya pengadaan bahan ajar kuliah ensambel gitar pada tingkat tinggi, yaitu untuk mahasiswa semester lima dan enam. Persoalan penting yang mendasari pembahasan artikel ini adalah: Bagaimana penerapan bentuk sonata pada bagian pertama Concerto G Mayor dengan solis flute, K.131, karya W.A. Mozart, peran ensambel gitar sebagai alternatif piano pengiring, penerapan temuan penelitian ini pada pengembangan bahan ajar ensambel gitar, dan penerapan tipe aransemen konserto pada proses pembelajaran ensambel gitar.

\section{Kajian Literatur dan Metode Penelitian}

Studi musikologi dalam konteks kajian musik klasik Barat, dengan obyek karya musik klasik di perguruan tinggi Indonesia jarang dilakukan. Sebagian besar Sarjana Seni yang memiliki latar belakang studi musik Barat justru membahas objek-objek lokal, antara lain: Sriwulan, et al. (2014: 52-70) mengkaji struktur, fungsi, dan makna talempong bundo dalam upacara Maanta 
Padi Saratuih; Indrawan (2010: 59-105) mengkaji seni pertunjukan Islamis selawatan di Daerah Istimewa Yogyakarta sebagai seni pertunjukan musikal. Beberapa kajian pada musik klasik Barat antara lain: komparasi elemen Barat dan lokal pada opera tradisional Batak (Batubara, 2013: 93-103), pendidikan musik klasik untuk anak di Indonesia (Sitowati, 2013:122-129). Kajian yang terdekat dengan penelitian ini ialah dari Wirayudha (2014: 100-106). Penelitian itu menggunakan repertoar dalam pembahasan teknik permainan cello, yaitu penerapan bentuk Sonata dalam wadah yang berbeda, namun Wirayuda hanya membahas pola problem-solution dalam teknik memainkan karya tersebut tanpa menyinggung analisis bentuk musiknya.

Untuk menjawab persoalan-persoalan yang mendasari kajian ini, maka dipergunakan metode penelitian musikologi dalam perspektif musik Barat. Metode ini khususnya diterapkan pada bidang pertunjukan instrumental penyajian ensambel gitar klasik dalam konteks pengembangan model pembelajaran musik di perguruan tinggi Indonesia. Sampel utama yang dijadikan model pelaksanaan pembelajaran ensambel gitar yaitu: repertoar konserto Klasik, dan peserta kuliah ensambel gitar yang dilaksanakan di Jurusan Musik, Fakultas Seni Pertunjukan, Institut Seni Indonesia Yogyakarta tahun 2013-2015. Pembahasan dalam artikel ini menggunakan metode komparatif, metode analitikal, metode transkripsi, dan metode penelitian tindakan (Watanabe, 1967: 5).

Metode komparatif musikologis diterapkan untuk membandingkan beberapa elemen dalam mengidentifikasi perbedaan dan persamaannya, metode ini berguna untuk mengidentifikasi permasalahan dalam kelas ensambel gitar, sementara metode analitikal sesuai untuk memilahmilah karya yang diteliti ke dalam bagian-bagian berdasarkan kerangka musikal yang diterapkan untuk memahami sistem yang menghubungkan bagian-bagiannya. Pendekatan ini secara konkrit digunakan untuk mengetahui penggunaan bentuk sonata-allegro yang memakai pola ritornello pada. Pendekatan ini biasanya diterapkan untuk membantu pemusik dalam menginterpretasikan karya ke dalam penyajian musik. Pemahaman tentang structural dari pendekatan ini digunakan untuk memudahkan proses transkripsi.

Proses transkripsi dilakukan dengan menyalin ulang skor orkestra pada skor ensambel gitar dan melakukan berbagai adaptasi teknis sesuai dengan kapasitas instrumennya. Guna menyesuaikan dengan sifat alami instrumen yang digunakan solis, yaitu flute, maka pada transkripsi ini tidak dilakukan perubahan kunci nada dasar. Oleh sebab itu repertoar bahan transkripsi dipilih berdasarkan kebutuhan kunci-kunci yang lazim pada instrumen gitar, yaitu karya dengan nada-nada dasar bertanda mula satu hingga empat kruis dan satu mol.

Proses penelitian tindakan kelas atau classroom action research (AR) dalam diterapkan dalam proses penguasaan repertoar oleh peserta kuliah melalui siklus yang lazim, yaitu beberapa putaran hingga mencapai saat penyajian hasil pembelajaran dalam suatu pementasan tunggal berupa ensambel gitar. Penelitian tindakan kelas biasanya dilakukan dalam bidang pendidikan, khususnya terkait dengan tindakan yang dirancang oleh guru dalam proses pembelajaran di kelas untuk tingkatan pendidikan sekolah menengah. Penerapan metode ini dalam memecahkan permasalahan yang terdapat dalam kelas praktik ensambel musik, di tingkat pendidkan tinggi belum dilakukan.

Action research adalah pengembangan proses mengajar dan belajar yang disertai studi sistematik dari tindakan dan konsekuensinya. Biasanya dilakukan oleh seorang praktisi pendidikan yang menganalisis data dari tempat bekerjanya untuk meningkatkan kualitas dari praktik pekerjaannya. Jenis penelitian ini adalah salah satu model penelitian terapan (applied research) yang penelitinya aktif terlibat dalam lingkungan yang menjadi sebab penelitian tersebut dilakukan. Action research sangat sangat menunjang khasanah tradisi penelitian kualitatif yang biasa dilakukan dalam bidang-bidang antropologi, sosiologi, dan etnografi. Proses penelitian ini meliputi lima putaran tahap, yaitu: (1) pembuatan komitmen yang merupakan panggilan terhadap penyelidikan, (2) perancangan atau perencanaan studi dengan menyusuna daftar pertanyaan dan kemungkinan jawabannya, (3) memulai tindakan dengan pengumpulan data dan analisis atau melakukan pengamatan, (4) melakukan re- 
fleksi dengan memperbaiki pertanyaan yang telah dirumuskan sebelumnya, (5) mengembangkan tindakan atas dasar pengalaman sebelumnya (Rust dan Clark, tanpa tahun: 3-4).

Cohen et al., (2007), sebagaimana dikutip dalam Cain (2012:409-425), berasumsi bahwa penelitian pendidikan seringkali dikonseptualisasikan sebagaimana yang ditekankan oleh tiga paradigm teoretis yaitu: (1) positivist/saintific, (2) interpretif/ naturalistic, dan (3) critical theory. Paradigma pertama biasanya diasosiasikan dengan metode-metode kuantitatif sedangkan dua yang lainnya dengan metode-metode kualitatif. Cain (2012) menekankan bahwa penelitian tindakan oleh guru musik dalam paradigma partisipatif meliputi beberapa hal yaitu: a) menyertakan studi mandiri, b) melibatkan siswa, c) mempertimbangkan pengaruh konteks, d) melibatkan lebih dari satu putaran penelitian tindakan, dan e) mengkaitkan dengan, dan memberikan kontribusi pada pengembangan teori.

Data dalam penelitian ini diperoleh dari survey proses pembelajaran ensambel gitar di beberpa perguruan tinggi Indonesia yang memiliki program sarjana seni untuk bidang musik. Sehubungan dengan itu pencarian data dilakukan pada program studi D3 dan S1 Seni Musik di HKBP Nomensen di Medan, ISI Padangpanjang, AKMR di Riau, ISI Denpasar, Universitas Pelita Harapan, dan Institut Kesenian Jakarta. Data dalam laporan ini adalah berdasarkan kunjungan penelitian pada Semester Gasal dan Genap Tahun ajaran 2014/2015.

\section{Pembahasan}

Menurut Kinkeldey dalam Apel (1965: 473) cakupan musikologi meliputi pengetahuan sistematik tentang musik yang menyeluruh sebagai hasil metode penelitian ilmiah, proses perkembangan musik, dan hubungan antar manusia. Berbeda dari pendapat sebelumnya, Amer (1973:211-212) mengatakan bahwa musikologi adalah studi kesarjanaan tentang musik yang meliputi hampir seluruh bidang musik, termasuk pendidikan musik. Walaupun Amer tidak menyertakan bidang pertunjukan dan komposisi, namun mengakui adanya penyertaan kedua bidang tersebut dalam kajian musikologi. Pendapat berikutnya dari Apel (1978:327) yang memberikan deskripsi lebih sistematis dan sederhana tentang musikologi. Menurutnya musikologi meliputi tiga bidang utama yaitu: (1) kajian historis yang berkaitan dengan seni musik Barat, (2) kajian komparatif atau dikenal dengan etnomusikologi, dan (3) kajian sistematik seperti ilmu akustika (fisika bunyi, seperti gelombang dan frekuensi bunyi musikal), psikologi, fisiologi, estetik, sosiologi, pedagogi dan teori musik (ilmu melodi, ritem, harmoni, kontrapung, dan sebagainya) Dewasa ini musikologi telah didefinisikan lebih longgar sehingga mencakup bidang-bidang kritik musik dan topik-topik yang berkaitan dengan pertunjukan musik. Kontribusi utama dalam kaitan dengan area-area tersebut adalah persiapan edisiedisi yang bertanggung jawab (Apel 1978:327). Jadi kedudukan transkripsi dalam praktek pertunjukan musik adalah sebagai bagian dari proses editorial.

Di antara beberapa sumber mengenai editorial musik yang berorientasi pada proses peyajian musik telah didiskusikan oleh Grier (1996). Editorial musik memiliki posisi dan hubungan yang erat dengan kajian-kajian musik lain seperti musikologi, ilmu filologi, sejarah musik, semiotika, gaya musik, dan komposisi. Grier berkesimpulan bahwa studi editorial merupakan cabang dari kritikisme historis. Editorial bermula dari penyelidikan kritis dan historis tentang penerapan pendekatan semiotika terhadap suatu teks musik. Pemahaman kritis editor tentang karya musik dalam konteks historis menyediakan kriteria akhir yang menentukan bentuk teks musik (1996:36).

Berbeda dengan pembahasan Grier (1996) yang lebih berorientasi pada piano, problematika editorial transkripsi gitar klasik memiliki kompleksitas yang lebih rumit. Konstruksi keyboard dan sistem notasi pendahulu piano (misalnya Spinet dan Harpsichord), tidak memiliki perbedaan yang signifikan dengan piano modern. Sementara itu evolusi fisik instrumen gitar dari abad ke abad memiliki perubahan yang lebih drastis terutama pada perubahan jumlah dawai, penalaan, ukuran, teknik bermain, dan cara duduk. Hal paling signifikan adalah perubahan dari notasi tablatur yang tidak mengacu kepada masalah tinggi dan rendah nada melainkan pada posisi jari ke notasi modern. 
Metode transkripsi dalam proses pengembangan repertoar gitar dari repertoar orchestra dilakukan oleh Indrawan (1997) yang merancang transkripsi gitar dari komposisi Peer Gynt Suite Opus 46 No 1 untuk orchestra karya Edvard Grieg. Transkripsi dilakukan tidak langsung dari skor orchestra melainkan dari versi reduksi piano yang memang merupakan versi asli dari komponisnya sendiri. Transkripsi diawali dengan penyalinan skor piano ke dalam software penulisan musik dengan teknik voicing, yaitu pemilahan alur polifonik. Tahap berikutnya adalah menyatukan hasil voicing yang terdapat dalam paranada ganda pada piano yang berkunci treble dan bass ke dalam paranada tunggal dalam kunci treble dengan tanda octave bass $\left(\mathrm{X}_{8}\right)$ di bawahnya, sehingga terbaca dalam tingkat ketinggian ( $p i t c h)$ yang berada satu oktaf lebih rendah daripada nada-nada yang tertulis, sesuai dengan sifat pitch gitar. Selanjutkan dilakukan penetapan dan pengubahan nada dasar yang sesuai dengan instrumen yang dituju dengan mempertimbangan kewajaran batasan registernya.

Sejak pertengahan era Romantik repertoar gitar klasik diperluas pada transkripsi non linear yang mengambil sumber-sumber dari instrumen yang berbeda, atau lintas instrumen (Kennedy, 1994:898). Pelopor transkripsi gitar dari piano yang paling terkenal pada paruh kedua era Romantik ialah Miguel Llobet dan Francisco Tarrega. Peningkatan produk-produk transkripsi tipe ini menjadi semakin lazim sejak gitaris Andres Segovia yang produktivitasnya melebihi kedua pendahulunya. Hingga kini para artis dan juga pedagog gitar (Witmyer, 2001; Norman, 1961; dan Saunders, 2015) gemar memproduksi karyakarya transkripsi dari piano, seakan-akan musik itu adalah sumber yang tidak habis-habisnya sebagai bahan transkripsi gitar, sementara publikasi musik ensambel gitar yang merupakan transkripsi dari repertoar orkestra masih sangat jarang.

Dari tayangan-tayangan domain publik melalui situs jaringan luas youtube dapat dimaklumi bahwa transkripsi karya-karya orkestra banyak dibuat, tetapi belum ditemukan produk-produk transkripsi konserto dengan solis instrumen orkestra melodis, khususnya Flute. Contoh hasil transkripsi ensambel gitar yang menggunakan repertoar orkestra sebagai sumber antara lain: (1) Symphony No. 5 karya Beethoven (diunggah oleh SGC Archives pada 3 Maret 2010) dan (2) Vivaldi, Estro Armonico, Op. 3-10 oleh Shiba Guitar Club (Shiba GC Archives, 29 Mei 2009); (3) Bohemian Guitar Orchestra memainkan karya orkestra Bizet, Ouverture de Carmen (diunggah oleh Petra Poláčková, 1 Januari 2009) dan (4) Symphony No.40, K. 550 karya Mozart (diunggah Petra Poláčková, 2 Januari 2009). Berdasarkan video yang diunggah dalam situs Youtube di atas terlihat bahwa hanya sedikit orkestra gitar memainkan komposisi konserto yang menampilkan solis instrumen non gitar, bahkan dapat dikatakan tidak ada sama sekali. Karya-karya konserto yang dibawakan dua orkestra gitar tersebut seluruhnya terbatas pada komposisi Barok yang umumnya berasal dari komposisi solo instrumen, seperti misalnya organ J.S. Bach - Organ Concerto BWV593(3) (Shiba GC Archives, 22 Mei 2009), sehingga tidak melibatkan instrumen lain (non-gitar) sebagai solis.

Berdasarkan analisis dengan menggunakan metode-metode di atas, temuan-temuan yang diperoleh meliputi:

\section{Hasil studi komparatif}

Berdasarkan studi lapangan di beberapa perguruan tinggi dalam hal silabus dan kurikulum, mata kuliah ensambel gitar pada seluruh program studi Seni Musik di Indonesia belum memiliki kesamaan standar. Walaupun menggunakan nama yang sama, yaitu Koor/ Orkes/Ensambel (KOE) terdapat perbedaan yang cukup mencolok dalam penyelenggaraan kuliah ensambel pada institusi tersebut. Beberapa fenomena yang teridentifikasi di antaranya diterapkan sebagai pilihan yang utuh selama enam semester sebagai kuliah wajib (ISI Yogyakarta) namun tidak ada kuliah orkestra lengkap. Sementara itu ada yang menerapkannya sebagai suatu kesatuan rangkaian tahap-tahap, misalnya dua semester pertama koor, dua semester berikutnya ensambel; ada lembaga yang menerapkan kelompok instrumen sejenis, tetapi ada juga yang menerapkan formasi musik kamar lintas instrumen, dan pada akhirnya orkes lengkap. AKMR Riau bahkan mensinergikan kuliah KOE dengan tugas akhir komposisi musik dan penyajian musik. 
Pemasalahan yang dihadapi oleh institusiinstitusi tersebut berbeda-beda, namun terdapat kecenderungan pola permasalahan yang sama, yaitu jumlah mahasiswa, kualitas mahasiswa yang diterima, dan kekurangan repertoar. Masalah-masalah tersebut saling berkaitan; misalnya, jumlah mahasiswa yang sedikit sedikit mempengaruhi model pembelajaran dan dengan sendirinya jenis repertoar ensambel yang tepat untuk kondisi tersebut. Demikian juga dengan kualitas mahasiswa yang tidak merata. Jika repertoar terlalu tinggi maka tidak dapat diterapkan secara merata, sedangkan jika terlalu rendah dibandingkan kualitas mahasiswa, maka dosen perlu memikirkan strategi pembelajaran berbeda.

Dari berbagai persoalan di atas, masalah utama yang dihadapi ialah keterbatasan repertoar sehingga cara mengatasinya serupa, yaitu membuat aransemen dan transkripsi dari instrumen lain. Institusi yang menerapakan transkripsi dari orkestra, antara lain IKJ dan ISI Yogyakarta, sementara lainnya belum melakukannya karena kendala teknis dan jumlah peserta kuliah. Aspek positif yang dilakukan oleh hampir semua institusi ialah memiliki output pembelajaran yang sama yaitu mampu tampil dalam konser di akhir semester.

\section{Hasil studi analitikal-teoritik}

Dari banyak komposisi konserto untuk orkestra dan solo tiup kayu, solis Flute dipilih dengan alasan warna suara dan dominasi volumenya yang tidak sekuat instrumen lainnya. Di samping itu jumlah pemainnya terbanyak dibandingkan dengan pemain tiup kayu lainya. Dari tipologi orkestrasinya akhirnya ditetapkan komposisi konserto dari periode Klasik awal dari komponis yang terkenal yaitu WA Mozart, pada gerakan pertama.

Hasil pengamatan melalui metode analitikal-teoretik menunjukan bahwa bahan transkripsi yang dipilih dalam penelitian ini, yaitu "Allegro maestoso" dari Concerto in G major for Flute, K.131 dari W.A. Mozart tersusun dari bentuk sonata. Identifikasi bentuk sonata pada karya ini memang tidak semudah karyakarya klasik di pertengahan era, karena masih terpengauh oleh gaya Barok, yaitu mengandung aspek-aspek polofonis yang masih menonjol pada sebagian besar seksinya. Di samping itu juga gaya ritornello yaitu pergantian bagian-bagian solo dan tutti (bersama-sama). Pada bentuk ini bagian eksposisinya terdiri dari dua kelompok tema atau disebut "eskposisi ganda." Pada bagian development tema ini bertransformasi dari $G$ mayor ke D mayor. Pada bagian rekapitulasi kedua kelompok tema tersebut kemudian kembali dalam kunci $G$ mayor. Tema pokok dan transposisinya, baik pada developmen maupun rekaiptulasi, terangkai dari pola-pola ritornello. Eksplorasi elaborasi motif-motif pada keseluruhan karya ini semuanya dikembangkan dari motif-motif bagian eksposisi.

\section{Hasil transkripsi}

Transkripsi yang dilakukan dengan menyalin notasi seluruh instrumen pada partitur orkestra dengan menggunakan software musik Encore 5.0. hasilnya, yaitu kelompok instrumen gesek biola pertama, biola kedua, viola, dan cello, didistribusikan kepada gitar 1, 2, 3, dan 4. Di atas skor kwartet gitar diletakkan staf notasi untuk solis, seperti pada skor orkes.

Instrumen-instrumen pendukung lain-nya, yaitu dua Oboe dan dua Horn in G di tulis di atasnya. Permasalahan untuk keempat instrumen pendukung tersebut ialah banyak nadanada panjang sementara durasi panjang nada tunggal pada gitar jauh lebih terbatas. Untuk mengatasi permasalahan tersebut nada-nada panjang dimainkan dengan teknik tremolo. Permasalahan lain ialah jangkauan atau register instrumen gitar yang lebih pendek dari biola, sehingga nada-nada tinggi di atas fret keduabelas sangat sulit untuk dimainkan. Bagian-bagian ini tentunya harus diturunkan satu oktaf dan berakibat pada penyesuaian harmoni yang tidak mudah. Solusi untuk masalah ini adalah menjadikan posisi harmoni dari terbuka menjadi tertutup tanpa mengubah esensinya. Untuk bagian kontrabass, yang pada dasarnya menggunakan notasi sama dengan cello namun satu oktaf yang lebih rendah, pada ensambel gitar digunakan bass akustik. Dari pengamatan penyajian ensambel gitar di situs Youtube, sebenarnya ada 
jenis-jenis gitar akustik yang setara dengan cello, dan juga gitar-gitar sopran yang bersuara tinggi (termasuk mandoline), sehingga warna suara ensambel dapat lebih dekat dengan orkes.

\section{Hasil penelitian tindakan}

Hasil aransemen ini diajarkan di kelas pada semester Gasal 2014 dan dievaluasi setiap empat kali pertemuan. Berdasarkan masukan baik dari dosen pengampu maupun mahasiswa peserta kuliah, dilakukan editorial dengan menghilangkan bagian-bagian tertentu yang tidak mengganggu struktur komposisi dan harmoni dan memperbaiki sistem penjarian pada bagian-bagian tertentu yang sulit. Di akhir semester ternyata kelas ensambel belum berhasil memainkan hasil transkripsi sesuai target yang diharapkan. Komentar yang umum dikemukakan oleh beberapa dosen dan sebagian besar mahasiswa ialah bahwa aransemennya secara teknis terlalu sulit.

Pada semester Genap 2014 dilakukan transkripsi ulang dari sumber reduksi piano agar lebih mudah jika ditransfer ke gitar, namun demikian pada semester Gasal 2015/2016 peserta kuliah tetap menganggap aransemennya sulit secara teknik. Akhirnya diputuskan bahwa hasil transkripsi pertamalah yang dijadikan prototipe adaptasi orkestra ke ensambel gitar, namun khusus untuk tingkat ketrampilan tinggi. Gagasan baru yang muncul setelah menerapkan kedua transkripsi lagu yang sama dari sumber yang berbeda ialah mencari bahanbahan reduksi piano yang lebih mudah, yaitu karya-karya Barok awal dengan solis rekorder. Perluasan repertoar untuk-tingkat-tingkat yang lebih rendah ternyata hingga saat ini dapat diterima. Hambatan mencari solis juga dapat diatasi dengan mengadaptasi permainan solo instrumen tiup pada permainan gitar sehingga menjadi karya ensambe gitar yang utuh.

\section{Penutup}

Perancangan ulang komposisi orkestra biasanya diterapkan dalam bentuk reduksi pada instrumen piano solo maupun duet. Bagian orkestra pada karya-karya konserto, yaitu komposisi orkestra yang menampilkan pemain solo instrumental sebagai solis, umumnya tersedia dalam publikasi piano pengiring yang bukan hanya digunakan dalam ujian tertutup namun juga dalam ujian terbuka seperti Resital Tugas Akhir. Reduksi piano dengan sendirinya banyak menghilangkan bagian-bagian tertentu dari detail-detail orkestra dan pada saat yang sama terdapat penyesuaian yang tidak sedikit terhadap kapasitas piano yang terbatas.

Dari segi produksi suara dan karakteristik produksi musikal gitar memiliki kesamaan dengan piano yang tidak dapat dipungkiri kondisinya. Meskipun demikian gitar memiliki kelemahan dibandingkan dengan piano dalam hal volume dan register. Jika dibandingkan dengan kelompok instrumen gesek (biola, viola, dan cello), gitar terdapat pada kelompok alat musik yang sama yaitu string, sementara piano berdiri sendiri. Dengan kelemahan dan kelebihannya, pada dasarnya gitar dalam formasi ensambel memiliki kelebihan dalam hal harmoni dan memainkan bagian-bagian orkestra secara lebih komprehensif yang tidak mungkin dapat dilakukan oleh piano. Dengan demikian sebuah ensambel gitar yang dirancang sedemikian rupa mampu mendekati penyajian orkestra dibandingkan dengan piano.

\section{Ucapan Terima Kasih}

Ucapan terima kasih disampaikan kepada Tuhan YME atas kesempatan baik yang telah diberikan. Selanjutnya ucapan itu juga disampaikan kepada Ditlitabmas, Kemenristek Dikti, dan para reviewer (s) yang telah memberikan kepercayaan untuk menjalani penelitian ini. Ucapan terima kasih juga diberikan pada Lembaga Penelitian Institut Seni Indonesia Yogyakarta atas segala dukungan dan bantuannya. Semoga Allah SWT senantiasa memberikan balasan dan hidayah-Nya.

\section{Kepustakaan}

Apel, Willi. 1944. Harvard Dictionary of Music. Cambridge: The Belknap Press of Harvard University.

Batubara, Junita, 2013. "Overture dalam Opera Kehidupan Dua Zaman-Hikayat Siboru 
Deakparujar: Penggabungan Elemen Opera Barat dan Opera Batak" dalam Resital: Jurnal Seni Pertunjukan Vol. 14 No. 2 Desember 2013, hal. 93-103.

Boer, Bertil van. 2012. Historical Dictionary of Music of the Classical Period. USA: Scarecrow press, Inc.

Broomhead, Paul. 2001. "Individual Expressive Performance: Its Relationship to Ensemble Achievement, Technical Achievement, and Musical Background" dalam Journal of Research in Music Education, Spring 2001 vol. 49 no. 1, 71-84.

Cain, T. (2012) “Too hard, too soft or just about right: theoretical underpinnings of music teachers' action research", dalam British Journal of Music Education, 29(3), 409-425.

Feldman, Martha, 1996, "Staging the Virtuoso: Ritornello Procedure in Mozart, from Aria to Concerto", dalam Neal Zaslaw (ed.), Mozart's Piano Concertos: Text, Context, and Interpretation, Ann Arbor: Uni-versity of Michigan Press

Grayson, David, 1998. Mozart: Piano Concerto No. 20 and 21. UK: Cambridge University Press.

Hackl, Stefan (ed.). 2008. Second Concertino pour la Guitare avec accompagniment de deux Violons, Alto \& Violoncelle par Jean Padovec. (Arsip manusktip).Texas: DGA Edition.

Hepokoski, James, dan Darcy, Warren, 2006, Elements of Sonata Theory: Norms, Types, and Deformations in the Late-Eighteenth-Century Sonata. Oxford: Oxford University Press.

Hutchings, Arthur, 2002, "Concerto", entri dalam Stanley Sadie, (2002), The New Grove Dictionary Seco"nd Edition Volume 6, New York., hal. 240.

Indrawan, Andre, 2010, "Selawatan sebagai seni pertunjukan musikal" dalam Resital: Jurnal Seni Pertunjukan, Vol. 11 No. 2 Desember 2010, hal. 59-105.

Keefe, Simon P. (ed.). 2005. The Cambridge Companion to the Concerto. UK: Cambridge University Press

Koner, Karen. 2008. "Wolfgang Amadeus Mozart's (1756--1791) Completed Wind Concertos: Baroque and Classical Design in the Rondos of the Final Movements". Tesis Master of Music. USA: The University of Arizona.

Leeson, Daniel N., and Robert D. Levin, 2005. “On the Authenticity of K. Anh. C14.01 (297b), a Symphonia Concertante for Four Winds and Orchestra, dalam Mozart Jahrbuch (Mjb) 1976-1977, hal. 70-96.

Lorenz, Michael. 2005. "The Jenamy Concerto", dalam Newsletter of the Mozart Society of America, x/1 (27 January 2005), 1-3.

Oracle Education Foundation. 2012. "The Classical Concerto" dalam Oracle Thinkquest dalam http://www.library.thinkquest.org/27927/ Classical_concerto.htm (di-download tanggal 19 Juni 2013; jam 10:00 WIB)

Richter, Annett Claudia. 2008. "Fiddles, Harmonicas, and Banjos: Thomas Hart Benton and His Role in Constructing Popular Notions of American Folk Music and Musicians". (Disertasi PhD). USA: UMI Microform, ProQuest LLC., University of Minnesota.

Rink, J., 2004, “The State of Play in Performance Studies", dalam J.W. Davidson (ed) The Music Practitioner, hal. 37-52. Aldershot: Ashgate.

Rust, Frances dan Clark, Christopher. (tanpa tahun). How to Do Action Research in Your Classroom. USA: Teachers Network Leadership Institute (TNLI).

Scholes, Percy A. 1938. The Oxford Companion to Music (10 $10^{\text {th }}$ Edition). London: Oxford University Press.

Sitowati, Inggit, 2013. "Kursus Musik Klasik sebagai Prestise dan Investasi Masa Depan Anak" dalam Resital: Jurnal Seni Pertunjukan Vol. 14 No. 2 Desember 2013, hal. 122-129. Sriwulan, Wilma ; Haryono, Timbul; Ganap, Vivtor; dan Simatupang, GR Lono L, 2014. "Struktur, Fungsi, dana Makna Talempong Bundo dalam Upacara Maanta Padi Saratuih" dalam Resital: Jurnal Seni Pertunjukan, Vol. 15 No. 1 Juni 2014, hal. 52-70

Tovey, Donald Francis, 1936. Normality and Freedom in Music, Oxford: Vladeron Press.

Watanabe, Ruth T. 1967. Introduction to Music Research. New Jersey: Prentice Hall, Inc.

Webster, James, 1996, “Are Mozart's Concertos 
'Dramatic'?: Concerto Ritornello versus Aria Introductions in the 1780". Dalam Neal Zaslaw (ed.), Mozart's Piano Concertos: Text, Context, and Interpretation, Ann Arbor: University of Michigan Press

Westrup, JA dan Harrison, F. LI. 1960. The New College Encyclopedia of Music. New York: W.W. Norton and Co.

Wier, Albert. 1938. The Macmillan Encyclopedia of Music and Musicians in One Volume. New
York: The Macmillan Co.

Wirayudha, Asep Hidayat, 2014. "A Solution to the Fingering Problem of Brahms Cellos Sonata No. 1 Opus 38 and Shostakovich Seolo Sonata Opus 40" dalam Resital: Jurnal Seni Pertunjukan, Vol. 15 No. 1 Juni 2014, hal. 100-106

Worthen, Douglas, 2008, "Mozart Flute Concerto in G Major, Allegro maestoso" Southern Illinois University Carbondale, OpenSIUC. 